ISSN 0258-7122 (Print), 2408-8293 (Online)

Bangladesh J. Agril. Res. 44(3): 569-576, September 2019

\title{
INCIDENCE OF RHIZOME ROT OF GINGER IN SOME SELECTED AREAS OF BANGLADESH AND THE CAUSAL PATHOGENS ASSOCIATED WITH THE DISEASE
}

\author{
M. M. ISLAM ${ }^{1}$, F. KHATUN ${ }^{2}$, M. I. FARUK ${ }^{3}$ \\ M. M. RAHMAN ${ }^{4}$ AND M. A. HOSSAIN ${ }^{5}$
}

\begin{abstract}
Ginger (Zingiber officinale L.) belongs to family Zingiberaceae is an important oriental spice crop. Ginger is high value crop which grows well in warm and humid climate and is cultivated from sea level to an altitude of 1500 meters above sea level (Kandinnan, et al. 1996). It has special significance for tropical countries where it is produced and consumed in large quantities (Islam, 2017; BARI, 2012, 2013 and 2014). The aromatic rhizomes are used as spice and medicine. Major producers of ginger in the world are India, Jamaica, Sierra Leone, Nigeria, China, Japan, Taiwan and Australia (Rana and Sharma, 1998). Ginger is much more used in Bangladesh as a spice and is cultivated more or less all over the country. In the country produced only 74380 metric tons of ginger from 9120 ha of land and the yield per hectare was $8.15 \mathrm{~kg}$ (BBS, 2011). But average yield is low as compared to other ginger growing countries of the world. The production is not enough to fulfill the annual requirement of the country. So every year a good amount of ginger is imported in exchange of foreign currency. Like many countries diseases are the major limiting factors for ginger cultivation in Bangladesh. Among the diseases, rhizome rot is the most devastating one caused by Pythium aphanidermatum, Fusarium oxysporum, Sclerotium rolfsii and Ralstonia solanacearum throughout the world (Chauhan and Patel, 1990; Dohroo et al. 1987 and Iyer, 1987). The pathogens involved decide the nature of the damage and symptom expression .The major pathogens involved with rhizome rot are viz., species of Pythium causing soft rot, Fusarium spp. causing yellows or wilt and Ralstonia solanacearum causing bacterial wilt (Elliot, 2003). Basal rot caused by Sclerotium rolfsii which appears later in the season in some cases. All these pathogens are known to form complexes with nematodes leading to synergistic effect on the severity of the disease. They predispose the crops to secondary pathogens (Sarma, 1994).Loss due to rhizome rot is estimated in many countries and the main pathogens associated with rhizome rot are the fungi such as Pythium spp. and Fusarium spp, bacteria like Ralstonia solanacearum and nematode (Elliot, 2003). It may cause losses to the extent of $50 \%$ or more due to soft rot ((Islam, 2017; BARI, 2012, 2013 and 2014; Joshi and Sharma, 1982) and sometimes total failure of the crops in the tropical regions of India (Fageria et al, 2006); 70\% rhizome
\end{abstract}

${ }^{1,3 \& 4}$ Senior Scientific Officer, Plant Pathology Division, Bangladesh Agricultural Research Institute (BARI), Gazipur, ${ }^{2}$ Chief Scientific Officer, Plant Pathology Division, BARI, Gazipur, ${ }^{5}$ Chief Scientific Officer \& Head, Farm Division, BARI, Gazipur, Bangladesh. 
production is reduced due to the infection caused by Pythium spp. and Fusarium spp. in Nepal (Anon., 2012) and 5-30\% losses occurred in Fiji and Australia by Pythium myriotylum (Stirling et al., 2009). Soil, water and infected planting materials are the main source of perpetuation of these pathogens (Dohroo, 2005). Pythium spp. is able to persist in soil over decay by means of encysted zoospores, oospores and sporangia. Pythium spp also can survive in air dry muck soil for up to 12 years (Hoppe, 1966). Pythium spread via infested rhizomes (Trujillo, 1964) and as oospores surviving in debris in the soil (Dohroo, 2005). Infection started from contaminated planting materials, saprophytically living fungus in the soil or on trash of previous ginger crops. The soft rot pathogen generally have quite a wide host range and can survive on other host plants so this makes it difficult to control in the field. In the past Pythium aphanidermatum was known as the sole causal agent of rhizome rot of ginger and was successfully controlled by the technology developed by Plant Pathology Division, BARI. But during the last few years that technology was not working well and it was noticed that some other fungal and bacterial association were involved with such rot. As the crop is cash crop so it is prime need to identify the causal agents of rhizome rot through intensive survey which will help to modify the existing technology for managing the disease in future. The present research work was undertaken to determine the incidence of rhizome rot of ginger and its causal agents.

A survey program was conducted in five districts namely Nilphamari, Rangpur, Bogra, Tangail and Khagrachari with a view to survey the incidence of rhizome rot during 2013-14. A total of 1156 farmer's field representing two upazilla from each district and at least 10 ginger fields from each upazilla were surveyed. The locations of survey were Upazilla of Sadar and Sayedpur of Nilphamari district, Sadar and Gangachara upazilla of Rangpur, Shibgong and Gabtali upazilla of Bogra, Madhupur and Ghatail upazilla of Tangail and Sadar and Dighinala upazilla of Khagrachari. Incidence of rhizome rot was estimated from each field following the formula of Sagar et al. (2008).

Percent Disease Incidence $=\frac{\text { Number of diseased plants counted }}{\text { Total number of plantscounted }} \times 100$

All samples were brought to laboratory and then tested in different media viz. $\mathrm{V}_{8}$ juice agar, Penta-chloro nitro-benzene (PCNB), Potato dextrose agar (PDA), nutrient agar and Tetrazolium Chloride (TZC) for isolation of fungus and bacteria.

Individual infected specimen of ginger rhizomes were washed with plain water and cut into small pieces of $1-1.5 \mathrm{~cm}^{2}$. The pieces were surface disinfected with $5 \%$ chlorox for $1 \mathrm{~min}$. Four pieces of pseudostems and rhizomes from each sample are placed in Petri plates containing V8 juice agar (Tsao and Ocane 1969) for Pythium, PCNB medium for Fusarium spp. (Nash and Snyder, 
1962) and PDA for other fungi. The inoculated plates were incubated at $26^{\circ} \mathrm{C}$. The V8 juice agar plates were incubated in the dark for 96 hours. The hyphal tips of fungi growing from those tissues samples were transferred to PDA slants for maintenance.

Pieces of infected pseudostems were placed in a small quantity of sterile distilled water for $20 \mathrm{~min}$ to allow bacteria to ooze out. A loop full of bacterial suspension was streaked on to TZC agar plates and the plates were incubated at $28^{\circ} \mathrm{C}$ (Kelma, 1954). Fluidal individual colony transferred to Casamino AcidPeptone Glucose Agar (CPG) and incubated for 48 hours; then again transferred to CPG slants and stored in sterile distilled water.

Pathogenicity of the isolates of Pythium, Fusarium, Sclerotium and Ralstonia was performed in the pothouse following standard protocol (Kelma, 1954). The ginger sprouts were raised by planting $30 \mathrm{~g}$ bits of seed rhizome in sterilized potting mixture with soil, sand and cowdung in 3:1:1 ratio. Forty five days old plants were used for inoculation and a control treatment without inoculation was maintained. Isolates of Pythium was grown on V8 juice agar. Fusarium and Sclerotium isolates were grown separately on potato dextrose agar. Ralstonia was grown on CPG medium. Seven days old cultures of Pythium, Fusarium and Sclerotium were harvested by washing mycelial mass with oospores/conidia and then suspended in $100 \mathrm{ml}$ of tap water and maintained by a magnetic stirrer. The mycelia/spore suspension was added to the bags around the hypocotyls at the rate of $50 \mathrm{ml}$ per bag. A $24 \mathrm{~h}$ old bacterial culture was harvested with a cotton swab and applied at the base of ginger plants by making injury to the roots of ginger plants in pots.

Observations were made every alternate day regarding development of rhizome rot and wilt symptoms of ginger. After the development of the typical symptoms of the disease, the pathogens were re-isolated and compared with original culture to prove the pathogenicity. Fungi under the genus Pythium aphanidermatum were identified with the use of keys of Hendrix and Papa (1974), and Fusarium oxysporum and Sclerotium rolfsii with Booth's key and for bacterium (Jenkins and Kelma, 1976). Incidence of Ralstonia solanacearum from pilai (mother seed rhizome) of ginger at different locations viz. Ramgarh, Tangail, Gazipur, Bogra, Khagrachari and Nilphamari during 2013-14 cropping season were also recorded.

The characteristic initial symptom of rhizome rot appearance was yellowing of leaves and in the early stages, a few tillers show symptom of yellowing. The yellowing symptom later spread to all the tillers and leaves become drooping, withering and drying. The infected shoot could be easily pulled out from the soil. The rhizome becomes water-soaked and mushy appearance (Plate 1). 

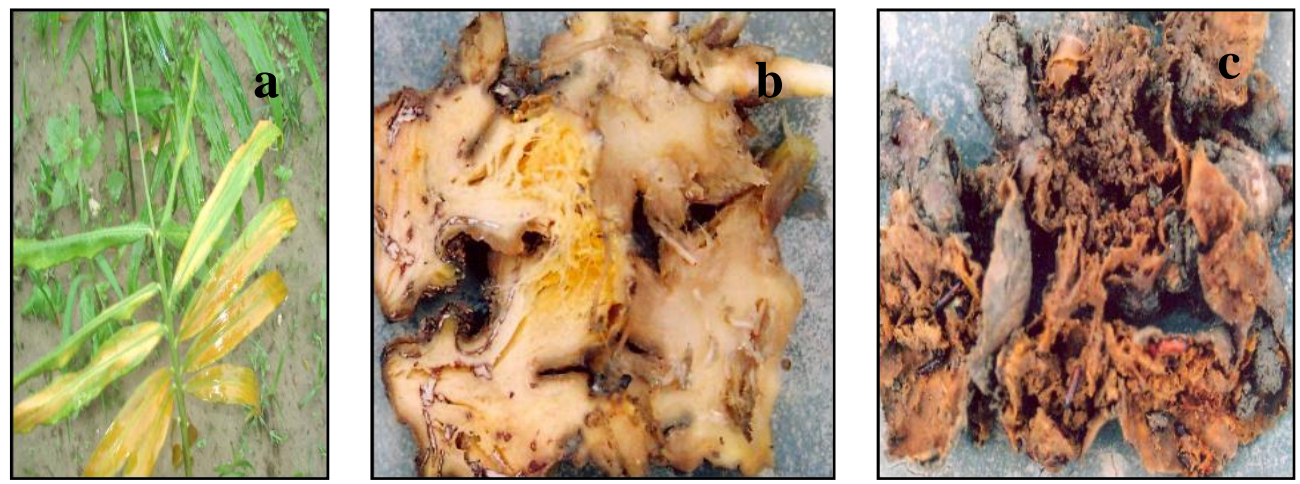

Plate 1. (a) \& (b) Plant, rhizome infected by Pythium, (c) tissue disintegration

Rhizome rot was noticed in all the locations with a range of $34.50 \%$ to $78.0 \%$ incidence ((Fig.1). The maximum disease incidence of $78.00 \%$ was recorded from Tangail followed by Nilphamari (46.70\%), Rangpur (38.00\%) Khagrachari $(35.50 \%)$ and Bogura $(34.50 \%)$. The information indicated that the disease incidence varied from locations to locations. The present findings are in agreement with Sagar et al. (2008). The authors stated that in Shimoga district, Karnataka of India the rhizome rot incidence was maximum $23.70 \%$ followed by Kadagu (22.90\%), Kannada (20.24\%) and Bidar (13.00\%) and the considered all the locations as 'hot spot' of rhizome rot disease of ginger.

Three fungal pathogens viz. Pythium aphanidermatum, Fusarium oxysporum and Sclerotium rolfsii; and a bacterium Ralstonia solanacearum were found to be associated with ginger (Plate 2). Pythium aphanidermatum found to be most predominant pathogen among the fungi.

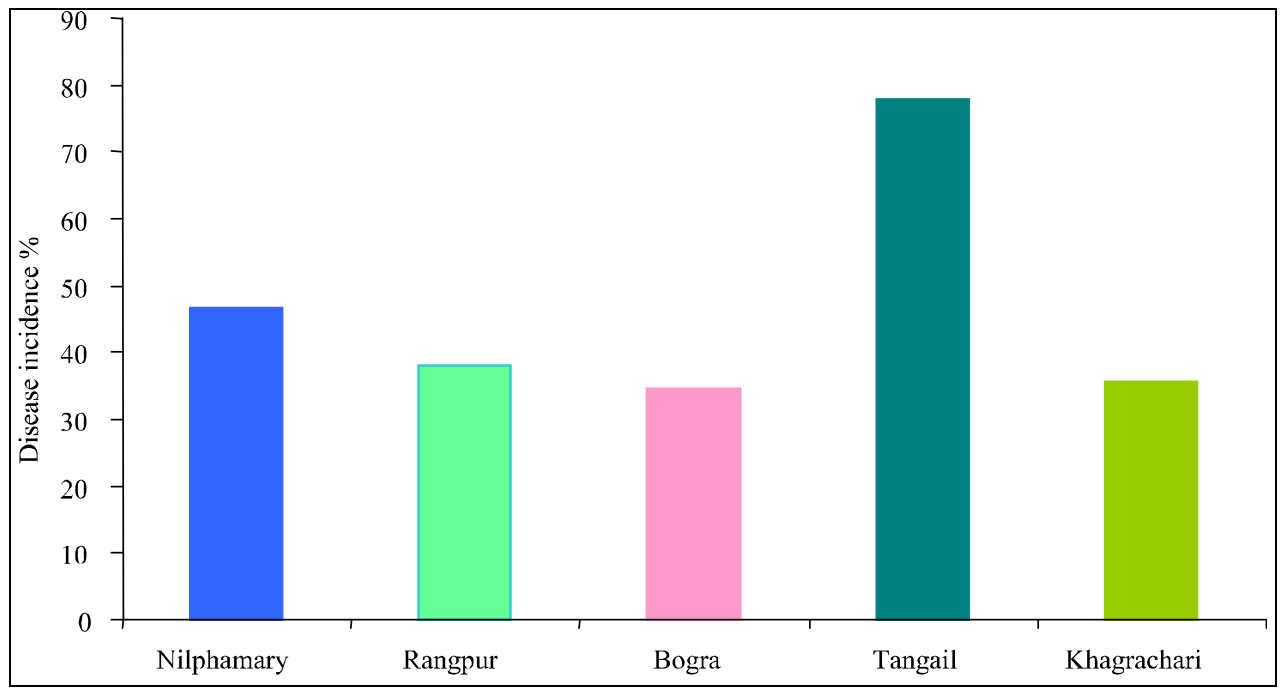

Fig.1: Incidence of rhizome rot disease of ginger in different districts 
Next predominant pathogen was Fusarium oxysporum; Sclerotium rolfsii and Ralstonia solanacearum. Results of the present study indicate that several pathogens were involved to cause rhizome rot of zinger. Pythium aphanidermatum and P. myriotylum; Fusarium oxysporum f.sp. zingiber and Ralstonia solanacearum were also reported from Kerala, India during a survey of rhizome rot of ginger in 1984 and 1985 (Dake and Edison, 1989).

Table 1 Pervalence of pathogens of rhizome rot of ginger collected from five different districts of Bangladesh during 2013-2014.

\begin{tabular}{l|c|c|c|c}
\hline Locations/Districts & $\begin{array}{c}\text { Pythium } \\
\text { aphanidermatum } \\
(\%)\end{array}$ & $\begin{array}{c}\text { Fusarium } \\
\text { oxysporum } \\
(\%)\end{array}$ & $\begin{array}{c}\text { Sclerotium } \\
\text { rolfsii } \\
(\%)\end{array}$ & $\begin{array}{c}\text { Ralstonia } \\
\text { solanacearum } \\
(\%)\end{array}$ \\
\hline Nilphamari & 41 & 25 & 14 & 12 \\
Rangpur & 35 & 25 & 9 & 15 \\
Bogra & 44 & 19 & 16 & 11 \\
Tangail & 46 & 26 & 11 & 8 \\
Khagrachari & 52 & 15 & 23 & 7 \\
\hline
\end{tabular}

It found that Pythium aphanidermatum caused maximum rhizome rot incidence in Khagrachari $(52 \%)$, followed by Tangail (46\%), Nilphamari $(41 \%)$ and Bogura (44\%) (Table 1). The pathogen caused the lowest infection in Rangpur (35\%). The highest (26\%) infection of Fusarium oxysporum was observed in Tangail followed by Nilphamari (25\%) and Rampur (25\%) while the lowest infection was found in Khagrachari and Bogura. The incidence of Sclerotium rolfsii varied from 9-23\% rhizomes in five districts. The pathogen caused the highest 23\% infection in Khagrachari while only 9\% rhizome infection was observed in Rangpur. The bacterium Ralstonia solanacearum was also found in some collected ginger samples. The highest $15 \%$ association of bacteria was found in Rangpur followed by $12 \%$ in Nilphamari and $11 \%$ in Bogra. The bacterial incidence was the lowest $7 \%$ in Khagrachari might be due to nonstagnant water in the field as compared to the plain land during rainy season. Results of the present findings show sharp variation of percentages of organisms in different locations. In a survey report made by Dake and Edison (1989) stated that $19.79 \%$ samples yielded Pythium aphanidermatum and P. myriotylum; $6.6 \%$ gave Fusarium oxysporum f.sp. zingiberi and $26.71 \%$ had Ralstonia solanacearum during a survey for rhizome rot of ginger in Kerala.

Symptom became apparent after 6 days of inoculation at $28^{\circ} \mathrm{C}$ in case of Ralstonia solanacearum where as it take 10 days to develop symptom on inoculated plant with Pythium aphanidermatum and Fusarium oxysporum. The symptoms exhibited wilting by the inoculated fungi and bacteria. Leaf margins with drooping symptoms were noticed five days after inoculation in case of $R$. solanacearum. Yellowing started from the inoculated leaf and progressed upward until all leaves gave a golden yellow appearance. The bacterium was present in 
infected pseudostem and rhizome, whereas in plants inoculated with Fusarium oxysporum; they became pale yellow followed by yellowing of the tips and then the infection spread along with the leaf margin and pseudostem became brown at collar region. The conspicuous symptoms exhibited by plants inoculated with Fusarium oxysporum were yellowing of leaves followed by drooping and drying of leaves and whole plants. The discoloration was also noticed at the hypocotyl portion of pseudostem.
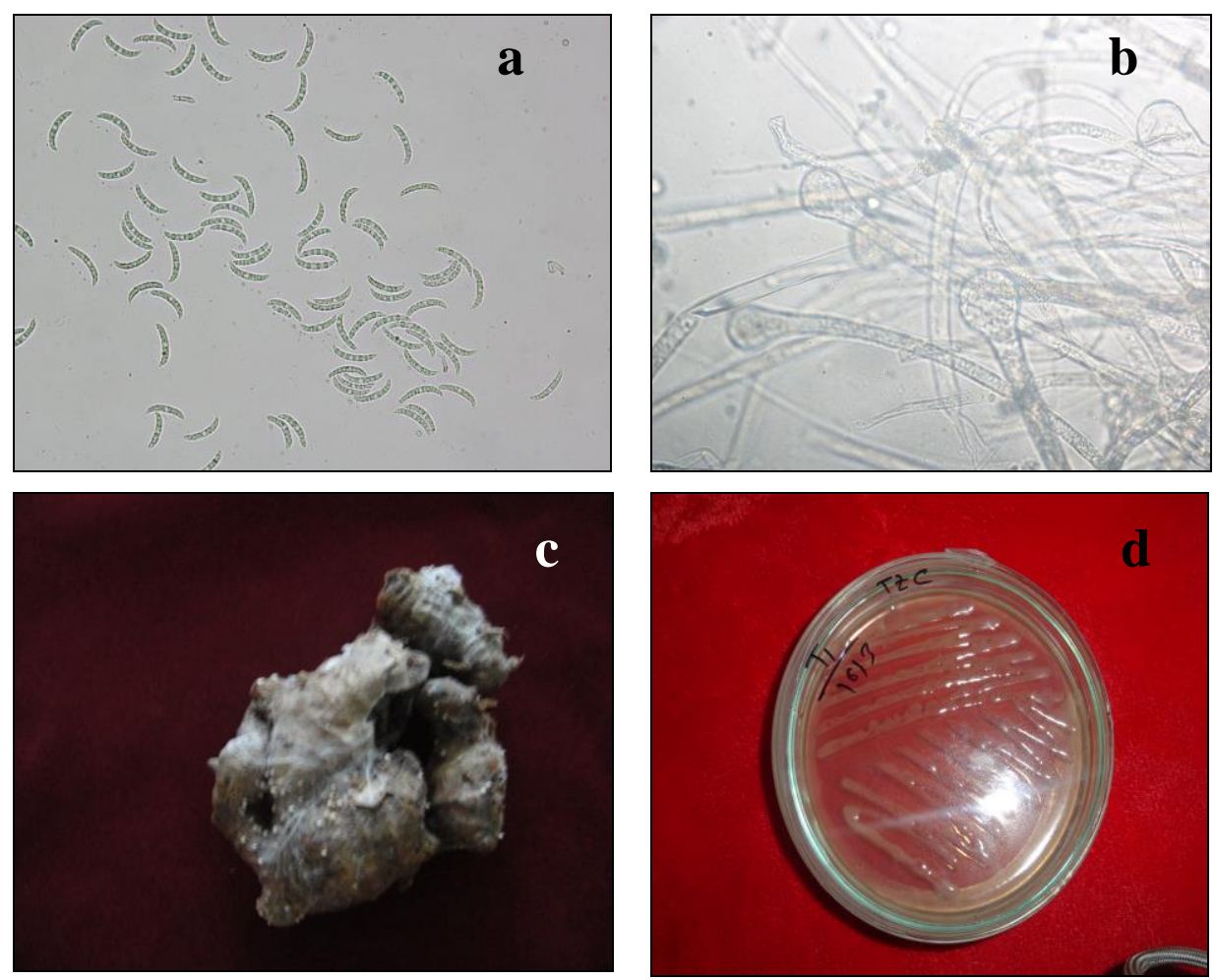

Plate 2. (a) Fusarium oxysporum (b) Pythium aphanidermatum (c) Sclerotium rolfsii and (d) Ralstonia solanacearum.

The incidence of Ralstonia solanacearum, the wilt causing bacterium from mother seed rhizome of ginger at different locations ranges from 40-67\% (Table 2). The highest infection 67\% was found in Tangail followed by 55\% in Nilphamri and the lowest (40\%) incidence recorded in Gazipur preceded by $45 \%$ at Bogra during 2013-14 cropping season (Table 2). Disease survey showed that 46.7, 38, 34.5, 78 and 35.5\% disease incidence was recorded in Nilphamari, Rangpur, Bogura, Tangail and Khagrachari, respectively. Findings of the present investigation show that causal pathogens of rhizome rot of ginger were Pythium aphanidermatum, Fusarium oxysporum, Sclerotium rolfsii and Ralstonia solanacearum in Bangladesh. These are involved in developing rhizome rot disease complex. 
Table 2. Incidence of Ralstonia solanacearum from mother seed rhizome of ginger at different locations during 2013-14 cropping season

\begin{tabular}{l|c|c|c}
\hline Location & $\begin{array}{c}\text { Seed rhizome } \\
\text { investigated }\end{array}$ & $\begin{array}{c}\text { Seed rhizome infected by } \\
\text { Ralstonia solanacearum }\end{array}$ & $\begin{array}{c}\text { Incidence } \\
(\%)\end{array}$ \\
\hline Khagrachari & 100 & 53 & 53.0 \\
Tangail & 100 & 67 & 67.0 \\
Gazipur & 100 & 40 & 40.0 \\
Bogra & 100 & 45 & 45.0 \\
Rangpur & 100 & 52 & 52.0 \\
Nilphamari & 100 & 55 & 55.0 \\
\hline
\end{tabular}

\section{References}

Anonymous. 2012. A report on value chain analysis of ginger in Nepal. Asia Network for Sustainable Agriculture and Bioresearches, 2011.

BARI, 2014. Survey on rhizome rot disease of ginger. Annual Research Report 2013-14, Department of Plant Pathology, Gazipur. P.140-144.

BARI, 2013.Survey on rhizome rot disease of ginger. Annual Research Report 2012-13, Department of Plant Pathology, Gazipur. P.139-141.

BARI, 2012.Survey on rhizome rot disease of ginger. Annual Research Report 2011-12, Department of Plant Pathology, Gazipur. P.128-129.

BBS. 2011. Monthly Statistical bulletin of the Bangladesh Bureau of Statitics (August). Administartion and MIS wing. Bangladesh Secretariate, Dhaka. P109.

Chauhan, H. L. and. Patel, M.H. 1990. Etiology of complex rhizome rots of ginger (Zingerber officinalae) in Gujrat and in-vitro screening of fungicides against its causal agents. Indian J. Agri. Sciences. 60: 80-81.

Dake, G. N and Edison, S.. 1989. Association of pathogens with rhizome rot of ginger in Kerala. Indian Phytopathology, 42(1):116-119.

Dohroo, N.P. 2005. Diseases of ginger. In: P. N. Ravindran and K. Nirmal Babu (eds,) "Ginger, the genus Zingiber". pp305-340. CRC Press, Boca, Raton.

Dohroo, N.P., Shyam , K.R. and Bhardwaj, S.S.. 1987. Distribution, diagnosis and incidence of rhizome rot complex of ginger Himachal Pradesh. Indian J. Pl. Pathol. 5: $24-25$.

Elliot, S. M. 2003. Rhizome rot disease of ginger. Crop and Plant Protection Unit, MOA. Jamaica, W.I. doi//moa.gov./jm/Plant Health/data/ginger_rhizome_rot_disease pdf.

Hendrix F. F. J. and Papa, K, E..1974. Taxonomy and genetics of Pythium. Prec. Amer. Phyto. Soc. 1: 200-207.

Hoppe, P. E. 1966. Pythium species still viable after 12 years in air dried muck soil. Phytopathology 56: 1411. 
Islam M.M., Golam Hafeez, ASM, Khalequzzaman, K.M., Reza M.H. and Hossain, M.M. 2017. Effect of botanicals and chemicals on rhizome rot disease of ginger. J. of Scientific Achievements, 2(12): 8-12

Iyer, R. 1987. Diseases of Ginger-Review. Trop. Pl. Pathol. 4: 251-288.

Jenkins, S and Kelma, A. 1976. Techniques for the study of Pseudomonas solanacearum. Proceedings 1st Int. Pla. Conf. and workshop on the ecology and control of bacterial wilt caused by Pseudomonas solanacearum. Releigh North Carolina, July1824,1976

Joshi, L.K. and Sharma, N.D. 1982. Diseases of ginger and turmeric. Pages 104-119. In: "Proceedings of the National Seminar on ginger and turmeric," Calicut. April 8-9 1980. Edited by Nair, M.K. Prem Kumar, T. Ravindra, P.N. and Sharma, Y.R. Published by CPCRI, Kasaragod, pp. 258.

Kandiannan K., Sivaraman, K., Thankamari, C.K. and Peter, K.V.. 1996. Agronomy of ginger (Zingiber officinale Rosc.). J. Spices and Agronomic Crops 5(1): 1-27.

Kelma, A. 1954. The relationship of pathogenicity in Pseudomonas solanacearum to colony appearance on tetrazolium. Phytopathology 44: 693-695.

Rahim, M.A. 1992. Spices and plantation crops in national economy. Proceedings, Sixth National Horticulture Convention and Symposium. Bangladesh Agricultural University, Mymensingh.

Sagar, S. D., Kulkarni, S.and Hedge, Y. R.. 2008. Management of rhizome rot of ginger by botanicals. J. Plant Sci. 2(2): 155-158.

Sarma, Y.R. 1994. Rhizome rot disease of ginger and turmeric. In: Advances in Horticultural Vol. 10 (Eds: Chadha K.L. and Rethinam P.). Malhotra Publishing House, New Delhi, pp. 1113-1138.

Stirling, G. R., Turaganivalu, U., Stir;ing, A. M., Lomavatu, M. F. and Smith, M. K.. 2009. Rhizome rot of ginger (Zingiber officinale) caused by Pythium myriotylum in Fiji and Australia. Australian Plant Pathology 38: 453-460.

Tsao, P., H. and Ocana, G. 1969. Selective isolation of species of Phytopthora from natural soils on an improved antibiotic medium. Nature 223: 636-638. 